\title{
IGF-I and IGFBP 3 in Growth Hormone Deficiency Role of Insulin Like Growth Factor-I (IGF-I) and IGF Binding Protein 3 in the Diagnosis of Growth Hormone Deficiency: Changing Paradigm
}

\author{
Kota SK' ${ }^{1}$ Jammula $S^{2}$, Gayatri K³, Kota SK ${ }^{4}$, Tripathy PR ${ }^{5}$, Modi KD \\ ${ }^{1}$ Dr. Sunil Kumar Kota, Department of Endocrinology, Medwin Hospital, Hyderabad, Andhra Pradesh, India, ${ }^{2}$ Dr. Sruti \\ Jammula, Department of Pharmaceutics, Roland Institute of Pharmaceutical Sciences, Berhampur, Orissa, India, ${ }^{3} \mathrm{Dr}$. Kotni \\ Gayatri, Department of Obstetrics and Gynaecology, Riyadh Care Hospital, Riyadh, Saudi Arabia, ${ }^{4}$ Dr. Siva Krishna Kota, \\ Department of Anaesthesia, Central Security Hospital, Riyadh, Saudi Arabia, ${ }^{5}$ Dr. Prabhas Ranjan Tripathy, Department \\ of Anatomy, Kalinga Institute of Medical Sciences, Bhubaneswar, Orissa, India, ${ }^{6}$ Dr. Kirtikumar D Modi Department of \\ Endocrinology, Medwin Hospital, Hyderabad, Andhra Pradesh, India.
}

Address for correspondence: Dr. Sunil Kumar Kota, E-mail: hidocsunil@ibibo.com

\begin{abstract}
GH stimulation tests are widely used in the diagnosis of GH deficiency (GHD), although they are associated with a high false positive rate. Serum IGF-I levels are monitored during GH replacement treatment in subjects with $\mathrm{GH}$ deficiency (GHD) to guide GH dose adjustment and to minimize occurrence of GHrelated side-effects. The need for reliance on provocative testing is based on evidence that the evaluation of spontaneous growth hormone (GH) secretion over 24 hours and the measurement of IGF-I and IGFBP-3 levels do not distinguish between normal and GHD subjects. Regarding IGF-I, it has been demonstrated that very low levels in patients highly suspected for GHD (i.e., patients with childhood-onset, severe GHD, or with multiple hypopituitarism acquired in adulthood) may be considered definitive evidence for severe GHD obviating the need for provocative tests. However, normal IGF-I levels do not rule out severe GHD and therefore adults suspected for GHD and with normal IGF-I levels must undergo a provocative test of GH secretion. We hereby review the various literatures at disposal justifying the use of IGF-1 and IGBP3 for diagnosis of growth hormone deficiency.
\end{abstract}

Data Source: We searched PUBMED and MEDLINE database for relevant articles including key words. References of each article were further reviewed for final synthesis of the manuscript.

Key words: Growth hormone deficiency, Insulin like Growth Factor 1,Insulin like growth factor binding protein 3.

\section{Introduction}

D lagnosis of growth hormone (GH) deficiency (GHD) is still a matter of debate. Assuming that no clinical feature can be relied on as a guide, the approach to diagnosis must include a high index of suspicion of hypothalamic-pituitary disease. At present, the insulin tolerance test (ITT) is the diagnostic tool of choice', even though this test is contraindicated in patients with electrocardiographic evidence or history of ischemic heart disease or in patients with seizure disorders. Other stimulation tests have proved their usefulness for GHD diagnosis but the maximum response for $\mathrm{GH}$ diagnosis has not been unanimously established in an adult population².

Insulin-like growth factors (IGFs) are polypeptides that act as endocrine mediators of growth hormone (GH)-induced anabolic and mitogenic actions. They also function in a paracrine and autocrine manner to regulate cell growth, differentiation, apoptosis and transformation. The IGF system is a complex network comprised of two growth factors (IGF-I and -II), cell surface receptors (IGF-IR and -IIR), high affinity binding proteins (IGFBP), IGFBP proteases as well as several 
other IGFBP-interacting molecules, which regulate and propagate IGF actions in several tissues ${ }^{3}$. The clinical use of measurements of IGF-I has been focused primarily on diagnosing or excluding GH deficiency (GHD) and monitoring GH therapy.

IGF-I and IGF-BP3 are being widely used for evaluation of the diagnosis of GHD. Owing to the limitations of $\mathrm{GH}$ stimulation tests, there has been a gradual shift from $\mathrm{GH}$-based approaches to those utilizing IGF for the diagnosis of GHD4 ${ }^{4}$. However, the use of IGF-I or IGF-BP3 in the diagnosis of GHD in children is a matter of controversy ${ }^{5,6}$ because of variable sensitivity and specificity of these tests $\mathrm{s}^{5,7,8}$.

Factors influencing levels of IGFs are age, sex, pubertal status, nutritional status, diabetes mellitus, renal failure and liver functions ${ }^{9}$. A reduced IGF-I level may occur in a child with malnutrition ${ }^{10}$, hypothyroidism ${ }^{11}$, hepatic disease, or diabetes mellitus ${ }^{12}$, as well as GHD. Pulsatile growth hormone $(\mathrm{GH})$ secretion stimulates GH-responsive issues to produce IGF-I. IGF-I in plasma is primarily derived from the liver and circulates bound to specific IGF-binding proteins (IGFBPs), six of which (IGFBP 1-6) have been characterized. Most (99\%) IGF-I circulates bound to IGFBP-3 in I50-kDa complex. Serum IGFBP-3 concentrations are directly proportional to $\mathrm{GH}$ concentrations and nutritional status. IGFBP3 is considered a good marker for the GH-IGF axis.

Both IGF-1 and IGF BP 3 are GH-regulated, but ageand nutrition-dependency often renders interpretation of results difficult, thus making it desirable for each laboratory to have its own normative data matched for age and body mass index (BMI). However, such data are not always available since their collection is expensive, time consuming and requires a high degree of collaboration between clinical and laboratory departments. Thus, it is common practice to make use of reference values provided by commercial assay manufacturers, which include values obtained in a group of control subjects, usually stratified by age and/ or sex, but lacking any information on body fatness measurement. Altered body composition, with increased body weight and body fat mass and decreased lean body mass, is a clinical characteristic of GHD and should be taken into account in the matched reference population Rosenfeld, et al have found that $18 \%$ of the putative $\mathrm{GH}$ deficient children had serum IGF-1 levels within the normal range for age, and $32 \%$ of normal short children had low IGF-1 levels ${ }^{4}$.

\section{The role of IGF-I in the diagnosis of growth hormone deficiency (GHD)}

$\mathrm{GH}$ secretion can either be measured through investigation of the pituitary or by monitoring markers that change as a consequence of $\mathrm{GH}$ action on its target tissues. The two most widely used and best-validated biochemical parameters are immunoassay measurement of either GH or IGF-I. The first reflects GH secretion while the second reflects $\mathrm{GH}$ action. Since $\mathrm{GH}$ secretion is pulsatile in nature ${ }^{13}, \mathrm{GH}$ provocative/stimulation tests are essential.

\section{GH stimulation tests have many fallacies:}

1. The insulin tolerance test has been considered the gold standard for the assessment of $\mathrm{GH}$ axis ${ }^{14}$. However, it has been associated with mortality and morbidity in children due to associated hypoglycemia.

2. There is no consensus as to which of the other agents are most suitable. The sensitivity and specificity of arginine and clonidine stimulation tests are $73 \%$ and $85 \%$, and $70 \%$ and $85 \%$ respectively ${ }^{6}$. There is no agreement on the cut-off $\mathrm{GH}$ levels for each assay (i.e., 7 or $10 \mathrm{ng} / \mathrm{mL}$ ) to define normality.

3. There is a problem of reproducibility and the tests are associated with a wide coefficient of variation ${ }^{15}$.

4. The most significant drawback of these tests has been the lack of normative data. Stimulated $\mathrm{GH}$ levels have little resemblance to the growth dynamics of some normal children ${ }^{6}$.

5. Prepubertal children with normal stature may fail to attain peak $\mathrm{GH}$ values more than $7 \mu \mathrm{g} / \mathrm{L}$ during $\mathrm{GH}$ provocative test ${ }^{6}$. In a study by Marin, et al. ${ }^{16}$, there was a high incidence of peak $\mathrm{GH}$ concentration consistent with GH deficiency among normal children, i.e. $61 \%$ in the prepubertal children had a $\mathrm{GH}$ peak less than $7 \mu \mathrm{g} / \mathrm{L}$.

With advancing puberty, the percentage of children with normal stature who failed to attain a $\mathrm{GH}$ level greater than $7 \mu \mathrm{g} / \mathrm{L}$ in response to arginine, insulin and standardized treadmill exercise declined from $61 \%$ at pubertal stage 1 to $44 \%$ at stage $2,11 \%$ at stage 3 , and $0 \%$ at stages 4 and 5 . Administration of estrogen to the prepubertal subjects raised the normal range for the peak $\mathrm{GH}$ response to the three tests. Thus, both puberty and estrogen administration significantly increase the peak $\mathrm{GH}$ response to exercise, arginine, or insulin in normal subjects.

Owing to the limitations of $\mathrm{GH}$ stimulation tests, there has been a gradual shift from $\mathrm{GH}$-based approaches to that utilizing IGF for the diagnosis of $\mathrm{GHD}^{4}$. The serum level of the major GH-dependent peptide IGF-I is stable during the day, due mainly to the complexing of IGF peptides with a family of IGF-binding proteins (IGFBPs) ${ }^{17}$. Thus the potential for assessing GH status with a single estimation of the circulating IGF-I level proved attractive 
and gave rise to the hope that eventually dynamic GH provocation tests may become unnecessary. Initially IGF assay problems were caused by interference from the presence of IGFBPs ${ }^{18,19}$. This problem has been overcome by using a variety of approaches including acid size exclusion chromatography before the IGF assay, blocking IGFBP-binding sites with an excess of the unmeasured IGF peptide (excess IGF-II for an IGF-I assay) or IGF analogs that do not bind to IGFBPs as radioligands ${ }^{10}$.

The sensitivity and specificity of IGF-I in the diagnosis of GH deficiency in children is a matter of controversy because:

1. The liver is the principal source of IGF-I in the circulation

2. Hepatic production of IGF-I is highly influenced by nutritional factors

3. It is possible that decrements in IGF-I expected with GHD are modified by nutritional status and other factors, such that only severe GHD produces a clear segregation of children who are deficient from those who are not.

4. IGF-I levels are not only affected by age and nutritional status but also by thyroid hormones and gonadal steroids. Therefore, the patient should be euthyroid and pubertal staging should be assessed prior to estimation of IGF-I. The IGF-I level is influenced markedly by age and pubertal development ${ }^{20,21,22}$. Particularly low concentrations of IGF-I occur in normal children younger than 5 $\mathrm{yr}$ of age. Therefore, the use of IGF-I estimation to distinguish between normal and GH-deficient children is less successful in this age group.

Nevertheless the measurement of serum IGF-I is useful since it can be derived from a single blood sample and checked frequently during evaluation, monitoring and treatment of a child with growth failure. Since IGF-I levels vary with ethnicity, it is important to generate population specific normal ranges through childhood and adolescence, incorporating all pubertal stages ${ }^{7,8}$. There is a paucity of Indian studies on IGF-I and IGF-BP3. Dehiya, et al. ${ }^{17}$ have analyzed levels of IGF-I and IGF-BP3 in healthy children and adolescents (from birth to 20 years of age) residing in Mumbai suburbs.

Recently, it has been argued that total IGF-I concentration, in analogy with thyroid and sex steroid hormones, may not reflect IGF bioactivity. Thus, measurement of the serum unbound IGF-I fraction (free IGF-I) might have greater physiological and clinical importance than its total concentration ${ }^{23}$. The ratio on a molar basis between IGF-I and the predominant IGF binding protein (IGFBP-3) has been reported to correlate with free IGF- $\left.\right|^{24}$ and has been proposed as an indirect measure of the easily dissociable circulating IGF- $\left.\right|^{25}$.

The performance of IGF-I has mostly been evaluated in children diagnosed as GH deficiency on basis of short stature, poor growth velocity and sub-optimal GH levels during 2 provocative tests. Blum, et al. ${ }^{7}$ found sensitivity and specificity of IGF-I to be $92 \%$ and $54 \%$ respectively, using their normal ranges, when applied to their subjects (mean age 11.2 years) with $\mathrm{GH}$ deficiency. The peak $\mathrm{GH}$ level was $10 \mathrm{ng} / \mathrm{mL}$ (in response to both arginine and insulin). Such a high degree of sensitivity has not been found in other studies. Poor specificity was related to the fact that low IGF-I levels are relatively common in normal prepubertal children. There are still doubts about which is the most appropriate cut-off line for patients with GHD. Moreover, misclassification of subjects may occur, while taking into account false positive and negative results during GH stimulation tests. Different researchers have used cut-off lines based on standard criteria, such as the $5^{\text {th }}$ percentile, the 10 th percentile, or 2 SD in relation to the mean. Based on these criteria, a performance of IGF-I has been reported in children in the diagnosis of GHD with a sensitivity ranging from $34-100 \%$ and a specificity

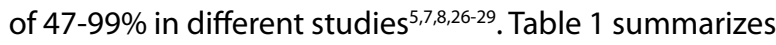
the specificity and sensitivity of IGF-I in various studies.

Table 1: The performance of IGF-1 in the diagnosis of Growth hormone deficiency

\begin{tabular}{|l|c|c|c|}
\hline \multirow{2}{*}{\multicolumn{1}{|c|}{ Studies }} & \multicolumn{2}{c|}{ IGF-1 } & $\begin{array}{c}\text { GH } \\
\text { Peak } \\
\text { level } \\
\text { (ng/mI) }\end{array}$ \\
\cline { 2 - 4 } & Sensitivity & Specificity & \\
\hline Granada, et al. (26) & $86.2 \%$ & $99.3 \%$ & 3 \\
\hline $\begin{array}{l}\text { Cianfarani, et al } \\
\text { (27) }\end{array}$ & $69 \%$ & $81 \%$ & 10 \\
\hline Mitchell, et al (28) & $62 \%$ & $47 \%$ & 13.5 \\
\hline Tillmann, et al (5) & $34 \%$ & $72 \%$ & $*$ \\
\hline Juul, et al (8) & $76 \%$ & $72 \%$ & $<7.5$ \\
\hline $\begin{array}{l}\text { Hasegawa, et al } \\
\text { (29) }\end{array}$ & $100 \%$ & $82 \%$ & 6 \\
\hline Blum, et al (7) & $92 \%$ & $54 \%$ & $<10$ \\
\hline
\end{tabular}

${ }^{*}$ Children with defined pathology e.g. Septo-optic dysplasia

Using $\mathrm{GH}$ testing as the gold standard to distinguish between 155 children with GHD and 219 with normal short stature, an IGF-I estimation at the fifth percentile level of the normal range provided a sensitivity of $95 \%$, specificity of $60 \%$, and accuracy of $75 \%$, while improved figures of $79 \%, 95 \%$, and $89 \%$, respectively, were associated with an IGF-I cut-off level of 0.1 centile $^{30}$. The IGF-I results discriminated better in those over 8 
yr compared with those under $8 \mathrm{yr}$ of age $\mathrm{e}^{30}$. Juul and Skakkebaek ${ }^{31}$ also concluded that measurement of IGF-I was useful in the diagnosis of childhood GHD but, unlike the findings reported by Blum ${ }^{30}$, more so in younger than older children. They reported accuracy (predictive value) of $88.8 \%$ and $52.3 \%$ in children aged less than 10 $\mathrm{yr}$ and between 10 and $20 \mathrm{yr}$, respectively ${ }^{31}$. In the latter studies ${ }^{30,31}$ the IGF-I values were corrected for age and sex but not pubertal status.

Despite the promise of these results, multiple studies exist that indicate the serum IGF-I concentration does not correlate perfectly with $\mathrm{GH}$ status, as determined by provocative $\mathrm{GH}$ testing ${ }^{32,33,34}$. To improve the diagnostic value of IGF-I measurements, the additional measurement of IGF-II has been recommended ${ }^{35}$. Despite the fact that IGF-II is less GH dependent than IGF-I, the normal range for IGF-II levels is relatively high in young children and shows little age dependence. Thus, although the accuracy of serum IGF-II measurement alone in detecting GHD is moderate, the combined use of IGF-I and IGF-II improves their value as a diagnostic parameter. In a study of $68 \mathrm{GH}$-deficient children, 197 normal-statured children, and 44 normal short children, $18 \%$ of the GH-deficient children had serum IGF-I levels within the normal range, whereas $32 \%$ of normal short children exhibited low IGF-I concentrations. Low IGF-II levels were found in $52 \%$ of $\mathrm{GH}$-deficient children but also in $35 \%$ of normal short children. Utilizing the results from both IGF assays, however, revealed that $4 \%$ of GHdeficient children had normal IGF-I and IGF-II levels but only $0.5 \%$ of normal children and $11 \%$ of normal short children had reduced concentrations of both IGF-I and IGF-II ${ }^{35}$. In reality, however, very few paediatric endocrine centres use IGF-II assays in the assessment of children with short stature.

Thus, low levels of IGF-I may be indicative of GHD. The plasma concentrations of the IGF-I could be considered useful indicators of $\mathrm{GH}$ bioactivity in children when correlated clinically, and accounting for other confounding factors. However, it is noteworthy that a normal serum IGF-I level does not exclude the presence of GHD.

\section{Role of IGF-BP3 in the diagnosis of $\mathrm{GH}$ deficiency (GHD)}

Of the six known IGFBPs, IGFBP-3 is normally the major serum carrier of IGF peptides ${ }^{36}$. IGFBP-3 circulates as part of a ternary complex consisting of IGFBP-3, an IGF peptide, and an acid-labile subunit ${ }^{37,38}$. Both acidlabile subunit and IGFBP-3 are GH dependent. Since IGFBP-3 determinations reflect combined IGF-I and IGF-II concentrations, age dependency of IGFBP-3 is less striking than for IGF-I.
Since IGFBP-3 serum levels are constant throughout the day and are closely GH dependent, it was proposed as a reliable and simple screening test in the work-up of children with short stature and preliminary results were promising. Blum, et $\mathrm{al}^{7}$ observed the sensitivity and specificity of IGF-BP3 to be $97 \%$ and $95 \%$ respectively. Moreover, IGF-BP3 measurement offers several important advantages over IGF-I determination ${ }^{28}$ :

1. No extraction step is required before measurement, thereby improving the precision and facilitating the procedure

2. IGFBP-3 normally circulates in the serum at high concentrations, so that assay sensitivity is not an issue.

3. IGFBP-3 serum concentrations, like IGF-I, are agedependent, but the normal range varies only modestly with age and pubertal status.

4. The impact of nutritional status is not as significant as with IGF-I.

Several studies have addressed the issue of sensitivity and specificity of IGFBP-3 assessment in the diagnosis of GHD, yielding conflicting results $5,7,8,26-29,39$ (Table 2).

Table 2: Performance of IGF BP 3in the diagnosis of Growth hormone deficiency

\begin{tabular}{|l|c|c|c|}
\hline \multirow{2}{*}{ Studies } & \multicolumn{2}{|c|}{ IGF BP 3 } & $\begin{array}{c}\text { GH } \\
\text { Peak } \\
\text { level } \\
\text { (ng/ml) }\end{array}$ \\
\cline { 2 - 4 } & Sensitivity & Specificity & \\
\hline $\begin{array}{l}\text { Granada, et al. } \\
\text { (26) }\end{array}$ & $70.4 \%$ & $96.7 \%$ & 3 \\
\hline $\begin{array}{l}\text { Cianfarani, et al } \\
\text { (27) }\end{array}$ & $27 \%$ & $100 \%$ & 10 \\
\hline Mitchell, et al (28) & $14.9 \%$ & $98 \%$ & 13.5 \\
\hline Tillmann, et al (5) & $22 \%$ & $92 \%$ & $*$ \\
\hline Juul, et al (8) & $68 \%$ & $79 \%$ & $<7.5$ \\
\hline $\begin{array}{l}\text { Hasegawa, et al } \\
\text { (29) }\end{array}$ & $92 \%$ & $69 \%$ & 6 \\
\hline Blum, et al (7) & $97 \%$ & $95 \%$ & $<10$ \\
\hline
\end{tabular}

* Children with defined pathology e.g. Septo-optic dysplasia

In a more recent evaluation of the usefulness of IGFBP-3 measurement in the diagnosis of GHD, Juul and Skakkebaek ${ }^{31}$ reported sensitivity and specificity figures of $60 \%$ and $97.9 \%$ in children less than $10 \mathrm{yr}$ of age and $56.5 \%$ and $78.7 \%$, respectively, in those aged between 10 and $20 \mathrm{yr}$. These results could not be reproduced in other studies ${ }^{32,40-43}$. Furthermore, the IGFBP-3 estimation discriminated particularly poorly between GHD and 
normality in pubertal children and those with radiationinduced $\mathrm{GHD}^{32,44}$.

Cianfarani et al reported poor sensitivity of IGFBP3 evaluation, suggesting that proteolysis is likely to affect IGFBP- 3 assay results ${ }^{39}$. Poor sensitivity of IGF binding protein (IGFBP)-3 assessment in the work-up of GH deficiency (GHD) has been ascribed to IGFBP-3 proteolysis $^{16}$. On the other hand, specificity of IGF-BP3 for the diagnosis of GHD has been generally reported by various studies to be high ${ }^{5,7,8,26-28}$.

It has been proposed that the measurement of the IGFBP-2 concentration adds to the value of IGF-I and IGFBP-3 assays in the diagnosis of GHD ${ }^{45}$. IGFBP-2 values are usually elevated in patients with $\mathrm{GHD}^{45,46}$. Despite the fact that in most patients there is agreement between the IGFBP-2/ IGF-I ratio, IGFBP-3 measurements, and the results of $\mathrm{GH}$ testing, the IGFBP-2/IGF-I ratio was discordant from thigh response in $21 \%$ of 80 patients (57 GHD and 23 idiopathic short stature), and IGFBP-3 results were discordant in $18 \%{ }^{45}$.

The proponents of IGF-I and IGFBP-3 estimations as the best choice of initial investigations in a child with possible GHD point out that in individuals with genetic forms of GH insensitivity (GHI), all have a low IGFBP-3 and most have a low IGF-I concentration ${ }^{47,48}$. By definition, these individuals have elevated $\mathrm{GH}$ concentrations associated with a mutation or deletion of the gene for the $\mathrm{GH}$ receptor, which renders them insensitive to $\mathrm{GH}$ action. Furthermore, despite the universally low IGFBP-3 concentrations and the characteristically severe growth failure, serum IGFBP-3 concentrations still correlate significantly with the height SDS $S^{47,49}$.

Thus, low levels of IGF-BP3 are very specific for the diagnosis of GHD, indicating its clinical utility. However, due to poor sensitivity of IGFBP3, normal serum level does not exclude GHD.

\section{IGF-1 and IGF-BP3 in the diagnosis of Adult GHD}

The changes in IGF-I levels throughout life are similar to those of $\mathrm{GH}$. With the onset of puberty there is a 2 to 3-fold rise in serum IGF-I concentrations followed by a decline such that average adult levels are reached by the early twenties ${ }^{22}$. There follows a gradual decline with advancing age ${ }^{22}$. Similar to IGF-I but less age-dependent, serum IGFBP-3 levels rise to a peak during the pubertal years and then slowly decline in adulthood ${ }^{49}$. Thus, in the adult patient with potential GHD, serum IGF-I and IGFBP3 measurements can only be interpreted if decadebased normative data are available. The usefulness of an IGF-I estimation in the diagnosis of adult GHD is a matter of contention although it has become clear that at least some of the disparity between studies is explained by the timing of the onset of GHD. Hoffman et al. ${ }^{50}$ found that $70 \%$ of IGF-I and $72 \%$ of IGFBP-3 values in adultonset GHD patients, mean age $45 \mathrm{yr}$, were within the range of normal subjects even allowing for the effects of age. Holmes ${ }^{51}$, in a subsequent study of 65 adults, mean age $35 \mathrm{yr}$, with GHD defined by a peak GH response of less than $3.8 \mathrm{ng} / \mathrm{ml}$ to a provocative test, and associated with other evidence of pituitary disease, found that $70 \%$ had an IGF-I SDS below 22. In the latter study, however, the 65 adults consisted of a mixture of childhood-onset and adult-onset $\mathrm{GHD}^{51}$.

DeBoer et al. ${ }^{52}$ focused on childhood-onset GHD and reevaluated $\mathrm{GH}$ status in 89 young adult males who had previously received $\mathrm{GH}$ replacement in childhood. Approximately $93 \%$ of the patients had an IGF-I level below the normal range with a similar number of subnormal IGFBP-3 levels among the patients (Fig. 1). Attanasio et al. ${ }^{52}$ pursued the same theme in a large study of 74 childhood-onset and 99 adult-onset GHD patients. They concluded that there are profound differences between these two forms of $\mathrm{GHD}^{53}$. With group data they observed that the serum IGF-I levels were below normal in both groups of $\mathrm{GH}$-deficient patients but were significantly lower in childhood-onset than adultonset GHD patients ${ }^{53}$. Other authors have made similar observations ${ }^{54,55}$. In these studies, however, it is not clear whether sufficient decade-based normative data were available or whether the severity of GHD was equal in the childhood-onset and adult-onset groups. Thus, apart from the potential impact of the timing of onset of GHD, it is possible that the severity of GHD influences the interpretation of IGF-I results.

To pursue this question further, Shalet et al ${ }^{56}$ have analyzed the IGF-I SDS results of the mixed population of 65 adults with childhood- and adult-onset GHD studied by Holmes ${ }^{51}$ in the context of the severity of GHD. A direct comparison of the IGF-I SDS with peak $\mathrm{GH}$ response was impossible due to the multiplicity of $\mathrm{GH}$ provocative tests used in that study ${ }^{51}$. Therefore, the IGF-I SDS data was stratified, in the context of additional pituitary hormone deficits, into those with GHDO, GHD1, GHD2, and GHD3 (Fig. 2). In each of the latter categories, there was a mix of adult-onset and childhood-onset GHD patients, thereby allowing a comparison of IGF-I status among groups with tightly defined degrees of GHD. The numbers were sufficient for statistical comparison in the GHDO, GHD1, and GHD3 groups and, in each category, the median childhood-onset IGF-I SDS is lower than the median adult-onset IGF-I SDS, reaching significance in two of the three groups (GHDO,23.83 vs.22.69, P50.239; GHDI, 25.75 vs. 22.03, P 5 0.022; GHD3, 26.28 vs. 22.09, $\mathrm{P} 50.0003)^{51}$. These observations suggest that for a given 
degree of GHD, the serum IGF-I concentration is lower in adults with childhood-onset compared with adultonset disease. The explanation for this latter observation is unclear; however, it supports the notion that an IGF-I estimation is more likely to be of diagnostic use in childhood-onset than in adult-onset GHD.

An additional observation needs to be made in the patients with adult-onset isolated GHD. Toogood et al. ${ }^{57}$ had shown previously that $24 \%$ of GHDO patients had a peak $\mathrm{GH}$ response of less than $1.9 \mathrm{ng} / \mathrm{ml}$ to an ITT. In the data of Holmes ${ }^{51}$, there are 11 patients in the GHDO group with adult onset disease, eight of whom have an IGF-I SDS below 22. Therefore, any therapeutic strategy to decide which $\mathrm{GH}$ deficient patients warrant a trial of $\mathrm{GH}$ therapy must allow for patients with isolated GHD, who on an individual basis may show as severe a degree of GHD as a patient with panhypopituitarism.

\section{Rational approach to the diagnosis of GHD}

Normal levels of IGF-I and IGF-BP3 do not exclude a diagnosis of GHD. The high specificity of IGF-I and IGFBP3 measurements suggests that while a combination of a low IGF-I and low IGFBP- 3 would be highly suggestive of GHD, significant number of children with GHD will have normal values for either of these two markers. Mitchell, et al..$^{28}$ have observed that, if, for a diagnosis of $\mathrm{GHD}$, the requirement were for both these tests to be positive, then $99 \%$ of children without GHD would be correctly identified; however, the sensitivity of this test was only $15 \%$. Hence, neither IGF-I nor IGFBP-3 alone is a surrogate marker for GHD nor even when analyzed in combination, they cannot be used as surrogate markers for GHD.

Tillmann, et al..$^{5}$ devised a scoring system for diagnosis of $\mathrm{GH}$ deficiency based on the positive predictive value of the $\mathrm{GH}$ stimulation test, and the IGF-I and IGFBP-3 levels. A high score was highly indicative of GHD, but was achieved by few patients. A normal IGFBP3 level, however, did not exclude GHD. GH stimulation test with a peak level more than $10 \mathrm{ng} / \mathrm{mL}$ was the most useful single investigation to exclude a diagnosis of GHD.

Peak GH response to two different provocative tests less than 7 or $10 \mathrm{ng} / \mathrm{mL}$ has been considered previously as essential for the confirmation of $\mathrm{GHD}^{6}$. However, in a study by Cianfarani, et al. ${ }^{58}$, a simple assessment of height velocity (HV) and basal IGF-I in association with only one GH stimulation test, has been shown to confirm the diagnosis of GHD in a majority of patients.

It is useful to schedule IGF-I and IGF-BP-3 to study abnormalities of GH-IGF axis, and as part of initial screening and diagnostic workup in short children. This should be followed by GH provocative tests for making a definitive diagnosis of $\mathrm{GHD}^{59}$. Thus a rational diagnostic approach to the diagnosis of GH deficiency should emphasize good history and auxologic measurements, evaluation of IGF-I and IGF-BP3 levels to identify GH-IGF axis abnormalities, and finally confirmed by $\mathrm{GH}$ provocative tests ${ }^{60}$.

\section{Conclusion}

Thus, low IGF-I and IGFBP-3 concentrations are reliable guides to the diagnosis of severe GHD, provided the investigator considers the alternative possibilities of malnutrition, hypothyroidism, liver disease, and GHI. Discrepancies between IGF-I and IGFBP-3 results compared with the $\mathrm{GH}$ responses to dynamic tests exist, however, in those children believed to have lesser degrees of GHD. The inadequacies of dynamic provocative tests of $\mathrm{GH}$ release, outlined previously, may explain the discrepancies in the $\mathrm{GH}$ status defined by the $\mathrm{GH}$ and IGF axis results. Alternatively, it may be that IGF-I and IGFBP-3 estimations are less useful than the peak $\mathrm{GH}$ response to provocative testing in children with $\mathrm{GH}$ insufficiency.

We conclude that measurements of IGF-I and IGFBP3 are useful as screening tests for the diagnostic work up of short children. These screening tests should be followed by $\mathrm{GH}$ provocative test for making the definitive diagnosis of $\mathrm{GH}$ deficiency. $\mathrm{GH}$ provocative test still remains the single most useful investigation for the diagnosis of GHD.

\section{References}

1. Growth Hormone Research Society. Consensus guidelines for the diagnosis and treatment of adults with growth hormone deficiency: summary statement of the Growth Hormone Research Society workshop on adult growth hormone deficiency. J Clin Endocrinol Metab 1998;83:379-81.

2. Aimaretti G, Corneli G, Razzore P, Bellone S, Baffoni $C$, Arvat $E$ et al. Comparison between insulininduced hypoglycaemia and growth hormone (GH)releasing hormoneparginine as provocative tests for the diagnosis of GH deficiency in adults. J Clin Endocrin Metab 1998;83:1615-18.

3. Lelbach A, Muzes G, Feher J. The insulin-like growth factor system: IGFs, IGF-binding proteins and IGFBPproteases. Acta Physiol Hung 2005;92:97-107.

4. Rosenfield GR, Cohen P. Disorders of growth hormone/insulin like growth factor and action. In: Pediatric Endocrinology. Ed. Sperling MA. Philadelphia; WB Saunders, 2002, p. 211-288. 
5. Tillmann V, Buckler JM, Kibirige MS, Price DA, Shalet SM, Wales JK, et al. Biochemical tests in the diagnosis of childhood growth hormone deficiency. J Clin Endocrinol Metab 1997;82:531-54.

6. Clayton FE. The role of insulin like growth factors in the diagnosis of growth hormone deficiency. In: Growth Hormone therapy in KIGS: Ten years experience. Ed. Ranke MB, Wilton P. Heidelberg Leipzig, Germany, Johann Ambrosius Barth Verlag 1999; p. 53- 64.

7. Blum WF, Ranke MB, Kietzmann K, Gauggel E, Zeisel $\mathrm{HJ}$, Bierich JR. A specific radioimmunoassay for the growth hormone (GH)-dependent somatomedin binding protein: Its use for diagnosis of $\mathrm{GH}$ deficiency. J Clin Endocrinol Metab 1990;70:1292-98.

8. Juul A, Kastrup KW, Pederson SA, Skakkebaek NE. Growth hormone $(\mathrm{GH})$ provocative retesting of 108 young adults with childhood-onset $\mathrm{GH}$ deficiency and the diagnostic value of insulin-like growth factor I (IGF-I) and IGF-binding protein-3. J Clin Endocrinol Metab 1997;82:1195-201.

9. Monzavi R, Cohen P. IGFs and IGFBPs: Role in health and disease. Best Pract Res Clin Endocrinol Metab 2002;16:433-47.

10. Rogol AD 1986 Serum insulin-like growth factors I and II concentrations and growth hormone and insulin responses to arginine infusion in children with protein-energy malnutrition before and after nutritional rehabilitation. Pediatr Res. 1986; 20:1122-1130.

11. Baxter RC, Brown AS, Turtle JR. Radioimmunoassay for somatomedin-C: comparison with radioreceptor assay in patients with growth disorders, hypothyroidism and renal failure. Clin Chem 1982;28:488-95.

12. Tamborlane $W V$, Hintz RL, Bergman $M$, Genel $M$, Felig P, Sherwin RS. Insulin infusion pump treatment of diabetes: influence of improved metabolic control on plasma somatomedin levels. N Engl J Med 1981;305:303-307

13. Strasburger CJ, Bidlingmaier M.Serum insulin-like growth factor (IGF) binding protein-3 and IGF-I levels during childhood and adolescence. A crosssectional study. Pediatr Res 1995;38:149-55.

14. Shah A, Stanhope R, Matthews D. Hazards of pharmacological tests of growth hormone secretion in childhood. BMJ 1992;304:173-74.

15. Hindmarsh PC, Swift PGF. An assessment of growth hormone provocation tests. Arch Dis Child 1995;72:362-67.
16. Marin G, Domene HM, Barnes KM, Blackwell BJ, Cassorla FG, Cutler GB. The effects of estrogen priming and puberty on the growth hormone responseto standardized treadmill exercise and arginine-insulin in normal girls and boys. J Clin Endocrinol Metab 1994;79: 537-41.

17. Dehiya RK, Bhartiya D, Kapadia C, Desai MP. Insulin Like Growth Factor-I, insulin like growth factor binding protein-3 and acid labile subunit levelsin healthy children and adolescents residing in Mumbai suburbs. Indian Pediatr 2000;37:990-997.

18. Rosenfeld RG, Lamson $G$, Pham H, Oh $Y$, Conover C, De-Leon DD, Donovan SM, Ocrant I, Guidice L. Insulin-like growth factor binding proteins. Recent Prog Horm Res 1990;46:99-163.

19. Powell DR, Rosenfeld RG, Baker BK, Liu F, Hintz RL. Serum somatomedin levels in adults with chronic renal failure: the importance of measuring insulin-like growth factor I (IGF-I) and IGF-II in acid chromatographed uraemic serum. J Clin Endocrinol Metab 1986; 63:1186-92.

20. RJ, Hintz RL, Rosenfeld RG. Somatomedins in adolescence: a cross-sectional study of the effect of puberty on plasma insulinlike growth factor I and II levels. J Clin Endocrinol Metab 1983;57:268-71.

21. Rosenfield RI, Furlanetto R, Bock D. Relationship of somatomedin $\mathrm{C}$ concentrations to pubertal changes. J Pediatr 1983;103:723-28.

22. Juul $A$, Bang $P$, Hertel NT, Main $K$, Dalgaard $P$, Jorgensen K, Muller J, Hall K, Skakkebaek NE. Serum insulin-like growth factor-I in 1030 healthy children, adolescents and adults: relation to age, sex, stage of puberty, testicular size and body mass index. J Clin Endocrinol Metab 1994;78:744-52.

23. Frystyk J, Skjaerbaek C, Dinesen B \& Orskov $H$. Free insulin-like growth factors (IGF-I and IGF-II) in human serum. FEBS Letters 1994;348:185-91.

24. Skjaerbaek C, Vahl N, Frystyk J, Hansen TB, Jorgensen JOL, Hagen $C$ et al. Serum free insulin-like growth factor-I in growth hormone-deficient adults before and after growth hormone replacement. European J Endocrinol 1997;137:132-37.

25. Juul A, Main K, Blum WK, Lindholn J, Ranke MB \& Skakkebaek EN. The ratio between serum levels of insulin-like growth factor (IGF)-I and IGF binding proteins (IGFBP-1, -2, and -3) decreases with age in healthy adults and is increased in acromegalic patients. Clin Endocrinol 1994;41:85-93.

26. Granada ML, Murillo J, Lucas A, Salinas I, LopisMA, Castells I, et al. Diagnostic efficiency of serum IGF-I, 
IGF-binding protein-3 (IGFBP-3), IGF-I/ IGFBP-3 molar ratio and urinary $\mathrm{GH}$ measurements in the diagnosis of adult GH deficiency: importance of an appropriate reference population. Eur J Endocrinol 2000;142:243-53.

27. Cianfarani S, Liguori A, Boemi S, Maghnie M, lughetti $L$, Wasniewska $M$, et al. Inaccuracy of insulin-like growth factor (IGF) binding protein (IGFBP)-3 assessment in the diagnosis of growth hormone (GH) deficiency from childhood to young adulthood: association to low GH dependency of IGFII and presence of circulating IGFBP-3 18- kilodalton fragment. J Clin Endocrinol Metab 2005;90:6028-34.

28. Mitchell H, Dattani MT, Nanduri V, Hindmarsh PC, Preece MA, Brook CGD. Failure of IGF-I and IGFBP-3 to diagnose growth hormone insufficiency. Arch Dis Child 1999;80: 443-47.

29. Hasegawa $Y$, Hasegawa T, Tadaka M, Tsuchiya Y. Plasma free insulin-like growth factor I concentrations in growth hormone deficiency in children and adolescents. Eur J Endocrinol 1996;134:184-89.

30. Andersson AM, Orskov $H$, Ranke MB, Shalet SM, Skakkebaek NE. Interpretation of $\mathrm{GH}$ provocative tests: comparison of cut-off values in four European laboratories. Eur J Endocrinol 1995;132:340-43.

31. Juul A, Skakkebaek NE. Prediction of the outcome of growth hormone provocative testing in short children by measurement of serum levels of insulinlike growth factor 1 and insulin-like growth factor binding protein 3. J Pediatr 1997;130:197-204

32. Tillmann V, Buckler JMH, Kibirige MS, Price DA, Shalet SM, Wales JKH, Addison MG, Gill MS, Whatmore AJ, Clayton PE. Biochemical tests in the diagnosis of childhood growth hormone deficiency. J Clin Endocrinol Metab 1997; 82:531-35.

33. Moore DC, Ruvalcaba RHA, Smith EK, Kelley VC. Plasma somatomedin-C as a screening test for growth hormone deficiency in children and adolescents. Horm Res 1982;16:49-55

34. Reiter EO, Lovinger RD. The use of commercially available somatomedin-C radioimmunoassay in patients with disorders of growth. J Pediatr 1981;99:720-24.

35. Rosenfeld RG, Wilson DM, Lee PDK, Hintz RL. Insulinlike growth factors I and II in the evaluation of growth retardation. J Pediatr 1986;109:428-33.

36. Martin JL, Baxter RC. Insulin-like growth factor binding protein from human plasma purification and characterisation. J Biol Chem 1986;261:8754-60.
37. Furlanetto RW. The somatomedin $\mathrm{C}$ binding protein: evidence for a heterologous subunit structure. J Clin Endocrinol Metab.1980; 51: 12-19

38. Baxter RC 1988 Characterisation of the acid-labile subunit of the growth hormone-dependent insulinlike growth factor binding protein complex. J Clin Endocrinol Metab 1988;67:265-72.

39. Boquete HR, Sobrado PGV, Fideleff HL, Sequera AM, Giaccio AV, Suarez MG, et al. Evaluation of diagnostic accuracy of insulin-like growth factor, (IGF)-I and IGF-binding protein-3 in growth hormone-deficient children and adults using ROC plot analysis. J Clin Endocrinol Metab 2003;88:4702- 08.

40. Rosenfeld RG, Pham H, Cohen P, Fielder P, Gargosky $\mathrm{SE}$, Muller H, Nonoshita L, Oh Y. Insulin-like growth factor binding proteins and their regulation. Acta Paediatr [Suppl] 1994; 399:154-58.

41. Phillip M, Chalew SA, Kowarski AA, Stene MA. Plasma IGFBP-3 and its relationship with quantitative growth hormone secretion in short children. Clin Endocrinol (Oxf) 1993; 39:427-32 .

42. Cianfarani S, Boemi S, Spagnoli A, Cappa M, Argiro G, Vaccaro F, Manca Bitti ML, Boscherini B. Is IGF binding protein-3 assessment helpful for the diagnosis of GH deficiency? Clin Endocrinol (Oxf) 1995;43:43-47

43. Nunez SB, Municchi G, Barnes KM, Rose SR. Insulinlike growth factor-I and IGF-binding protein-3 concentrations compared to stimulated and night growth hormone in the evaluation of short children-a clinical research center study. J Clin Endocrinol Metab 1996;81:1927-32.

44. Sklar C, Sarafoglou K, Whittam E. Efficacy of insulinlike growth factor binding protein-3 in predicting the growth hormone response to provocative testing in children treated with cranial irradiation. Acta Endocrinol (Copenh) 1993;129:511-15.

45. Smith WJ, Nam TJ, Underwood LE, Busby WH, Celnicker A, Clemmons DR. Use of insulin-like growth factor-binding protein- 2 (IGFBP-2), IGFBP-3 and IGF-I for assessing growth hormone status in short children. J Clin Endocrinol Metab 1993;77:1294-99.

46. Clemmons DR, Snyder DK, BusbyWH. Variables controlling the secretion of insulin-like growth factor binding protein-2 in normal human subjects. J Clin Endocrinol Metab 1991; 73:727-33.

47. Guevara-Aguirre J, Rosenbloom AL, Fieldre PJ, Diamond FB, Rosenfeld RG. Growth hormone receptor deficiency in Ecuador: clinical and 
biochemical phenotype in two populations. J Clin Endocrinol Metab 1993;76:417-23.

48. Savage MO, Blum WF, Ranke MB, Postel-Vinay MC, CotterillAM, Hall K, Chatelain PG, Preece MA, Rosenfeld RG. Clinical features and endocrine status in patients with growth hormone insensitivity (Laron Syndrome). J Clin Endocrinol Metab 1993;77:146571.

49. Blum WF, Ranke MB, Kietzmann K, Gauggel E, Zeisel $\mathrm{HJ}$, Bierich JR. A specific radioimmunoassay for the growth hormonedependent somatomedin-binding protein: its use for diagnosis of GH deficiency. J Clin Endocrinol Metab 1990;70:1292-98.

50. Hoffman DM, O'Sullivan AJ, Baxter RC, Ho KY. Diagnosis of growth hormone deficiency in adults. Lancet 1994;343:1064-68.

51. Holmes SJ.5 Growth Hormone Replacement in Adults with Growth Hormone Deficiency. MDThesis. University of London, London, pp 141-152.

52. DeBoer H, Blok GJ, Van der Veen EA 1995 Clinical aspects of growth hormone deficiency in adults. Endocr Rev 1995;16:63-86.

53. PC, Valk NK, Hilsted J, Bengtsson BA, Strasburger CJ. Adult growth hormone deficient patients demonstrate heterogeneity between childhood onset and adult onset before and during human $\mathrm{GH}$ treatment. J Clin Endocrinol Metab 1997;82:82-88.
54. Beshyah SA, Anyaoku V, Newton P, JohnstonDG. Metabolic abnormalities in growth hormone deficient adults. 1. Serum insulin-like growth factor-I. Endocrinol Metab 1994; 1:167-72.

55. Janssen $\mathrm{YJH}$, Frolich M, Roelfsema F. A low starting dose of genotropin in growth hormone deficient adults. J Clin Endocrinol Metab 1997; 82:129-35.

56. Shalet SM, Toogwood A, Rahim A, Brennan MD. The Diagnosis of Growth Horlone Deficiency in Children and Adults. Endocrine Reviews 1998;19:203-23.

57. Toogood AA, Beardwell CG, Shalet SM. The severity of growth hormone deficiency in adult pituitary disease is related to the degree of hypopituitarism. Clin Endocrinol (Oxf)1994; 41:511-16.

58. Cianfarani S, Tondinelli T, Spadoni GL, Scire G, Boemi $S$, Boscherini B. Height velocity and IGF-I assessment in the diagnosis of childhood-onset GH insufficiency: Do we still need a second GH stimulation test? Clin Endocrinol 2002;57:161-67.

59. Ranke MB, Schweizer R, Lindberg A, Price DA, Reiter $E O$, Wikland $K A$, et al. Insulin like growth factors as diagnostic tools in growth hormone deficiency during childhood and adolescence: The KIOS experience. Horm Res 2004;62:17-25.

60. Preece MA. Making a rational diagnosis of growth hormone deficiency. J Pediatr 1997;131: 61-64.

\section{How to cite this article?}

Kota SK, Jammula S, Gayatri K, Kota SK, Tripathy PR, Modi KD. IGF-1 and IGFBP 3 in Growth Hormone Deficiency. Role of Insulin Like Growth Factor-1 (IGF-1) and IGF Binding Protein 3 in the Diagnosis of Growth Hormone Deficiency: Changing Paradigm. $J$ Nepal Paediatr Soc 2012;32(2):154-162. 